\title{
Prehistoric Indian Petroglyph
}

\author{
By Robert W. Nero, Saskatchewan Museum of Natural History
}

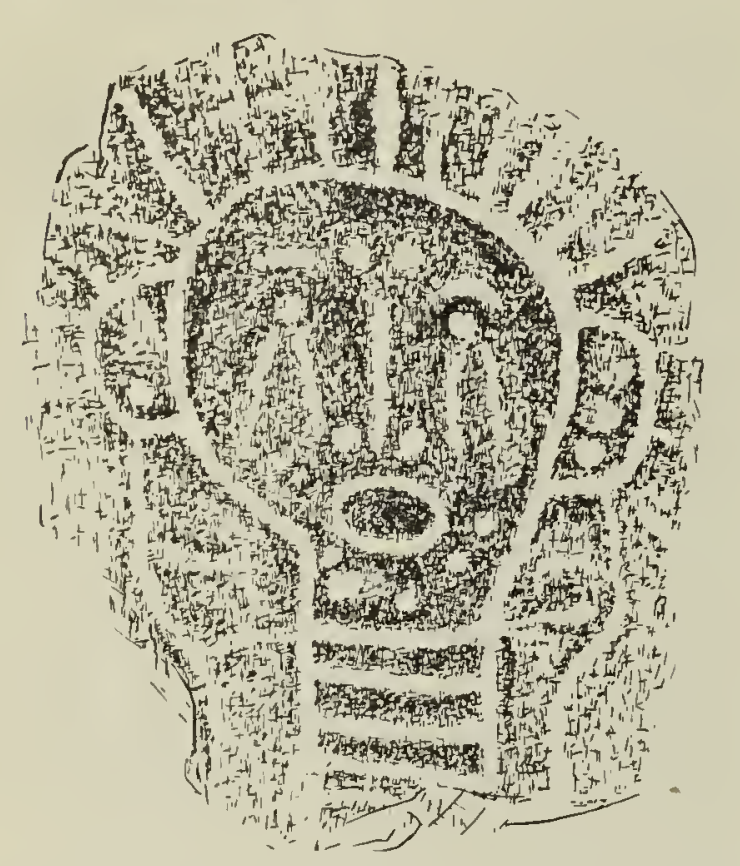

Sketch by Joyce Dew

The accompanying sketch was prepared by Joyce Dew from paper tracings after studying a large petroglyph found on a hilltop near Weyburn, Saskatchewan, by Victor
Mulhall in June of 1935. This granit boulder, weighing approximately 40 pounds and about two feet by one and-a-half feet in size, is now on dis play on the museum lawn.

This petroglyph and others like i which have been found in the north ern plains are believed to have beer associated with what is konwn a the Southern Death Cult, which wa a kind of religious revival in th lower Mississippi Valley and th southeastern United States about 40 years ago. The Death Cult parapher nalia at a later stage show consider able Mexican Indian influence Carved shell gorgets stone palette or plates, ceremonial batons of ston and other items related to the cul have also been found in Saskatche wan. The Death Cult is believed $t$ have died out farther south about 30 years ago, but there are records 0 its persistence into the historic perio in the central plains region.

\section{Folsom Point Found at Saskatoon}

\section{By H. Cronk, Saskatoon Artchaeological Socieity}

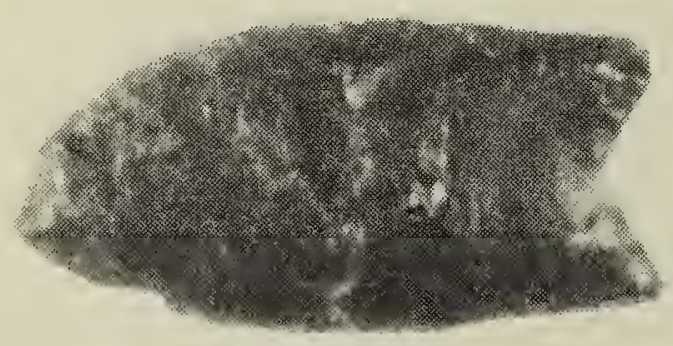

This is the point that the collector wants in his collection and the archaeologist, either amateur of professional, dreams of finding in situ. Why so much interest in this point? It is the find that pushed back many thousands of years the estimated date of man's coming to the continent. Before this find, 4,000 to 5,000 years was the accepted time of man's stay. It was the first type of artifact found associated with any of the long extinct Pleistocene animals. Dr. Figgins and his party were digging out the fossil remains of a species of giant bison near Folsom, New Mexico, in 1926 when he found some fragments of a man-made tool. Many experts in archaeology and anthropology refused to accept the fragments as man-made. But in 1927 when Figgins found a complete point lodged betwean the rib bones of a extinct bison, all digging stopped, an the doubting experts were sum moned. The evidence of associatio with the bones, and the fact tha these bones lay in deposits whic geologists identified as belonging $t$ the closing period of the Pleistocent was ample proof that man's sojour on the continent must be at leas 10,000 years.

The Folsom was vastly different $i$ shape and method of manufactur from any point that had been pre viously named. (A point is not name until a number have been found $i$ situ in one locality). The typical Fol som has a flute on each side runnin from the base nearly to the tip. Thi tluting is the result of a single flak being taken from the base toward th tip on each side after the point ha been otherwise fully shaped. Some those found at the Lindenmeier sit were only fluted on one side or no fluted at all. These may have been un finished points. The majority wer also ground or smoothed on the edge between the base and the widest pas of the point. 
Peculiar fluted points were found ith other types in 1924 by Kenneth Casey) Jones of Mortlach on the urface of sand blows. They were so ifferent that $\mathrm{Mr}$. Jones prized them reatly. At that time, the Folsom oint was archaeologically unknown nd therefore was not described in ny literature. If Kenneth Jones had bund these points in situ as did Dr. iggins, Mortlach would probably ave been the name-not Folsom.

The Saskatoon point in the accomanying picture agrees nicely with ie average classic Folsom from the
Lendenmeier site. It was found accidentally in the summer of 1957 by a member of the Saskatoon Archaeological Society, but was not reported until the December meeting of the Society as the importance of the find was not realized. No associated material was noticed in the trench at at the time of the find. It was found about 12 inches below the present surface and some of the soil above appeared to have been disturbed previously. 'The Society will make an investigation of the site as soon as weather permits.

\section{Folsom Fragment Found Near Woodrow}

By A. J. Hudson, Mortlach

In the summer of 1957 I was so rtunate as to find a fluted flake ear the junction of Wood River and into Creek. If you examine the lustrations of this Folsom point you ill notice a difference in the fluting the two sides. The flake of the
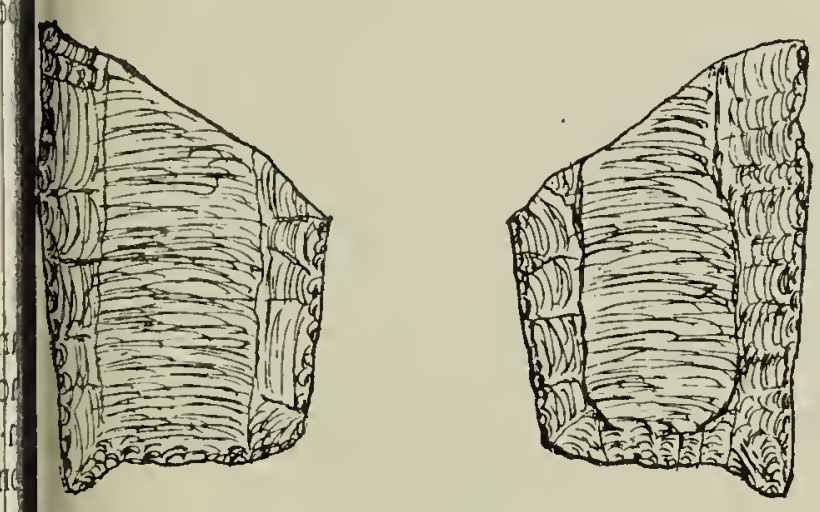

lsom fragment, chalcedony heavily patinated. Natural size.

side has been taken off from the se. In the process of making the int, the body is flaked on both les leaving a high central ridge and flat end at the base for a striking atform. I should guess that the ece must then be wedged in a block wood to get the proper resistances. mething in the form of a chisel ust have been used and a hard blow uck because of the need for curacy to get the first flake off. it with the flake on the reverse side difficulty arises. Unless the maker careful he is liable to break the int when striking off the second ig flake. In the present case, A2, striking platform has been made ward from the base and then the ke struck off. Finally a few thinig flakes have been taken out from base to bring the main flake scar sh with the base.
In the case of the two Folsom points owned by Mr. Conrad Dahl of Roseray. Saskatchewan, the problem has been met in a different way. One flake was taken out completely on one side, but on the cther side the flakes have been taken out piecemeal, i.e., a number of long, narrow flakes - safety first, so to speak. I examined Conrad Dahl's two Folsoms carefully one day and we decided that there was a strong possibility that the points were shaped after the fluting was done.. If the top end was left unfinished till the fluting was done, there would be less danger of shattering.

With the discovery of these Folsom points we're right on the trail of early man.

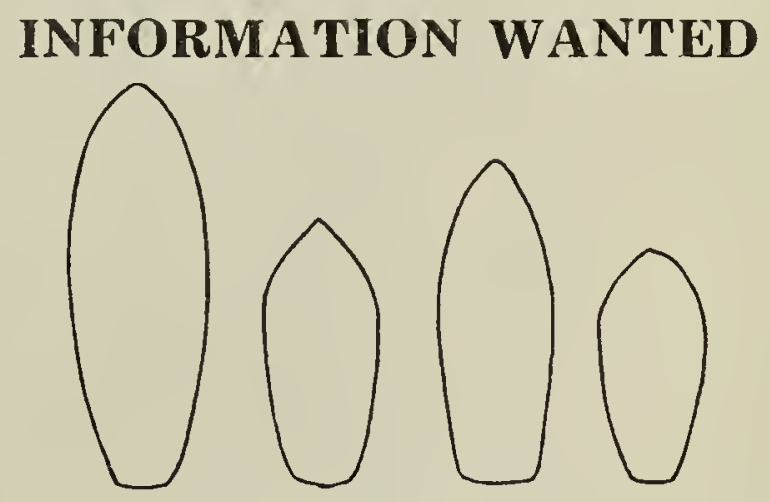

Information concerning the distribution of lanceolate projectile points in Saskatchewan and adjacent regions would be appreciated. The sketched outlines are of lanceolate points from the Parkhill site, south of Mcose Jaw, believed to be 7,000 to 8,000 years old. The largest point is just under three inches in length

Robert W. Nero,

Saskatchewan Museum of Natural History. 